\title{
THE CLIMATE CHANGE RELATED ADAPTATION AND RESILIENCE OF TRADITIONAL TRADICIONAL DWELLINGS: THE CASE OF THE YUCATAN PENINSULA
}

\section{AUDEFROY Joel F. ${ }^{1}$ CABRERA SÁNCHEZ Bertha Nelly ${ }^{2}$}

${ }^{1}$ Joel F. Audefroy, ICOMOS Mexicano BCE, Instituto Politécnico Nacional https://orcid.org/0000-0002-4308-4529

${ }^{2}$ Bertha Nelly Cabrera Sánchez, Instituto Politécnico Nacional

https://orcid.org/0000-0001-7485-5982

ABSTRACT: Mexico has been affected by extreme events such as storms, hurricanes, floods, and wildfires in the past ten years. In this paper, we will attempt to respond to the following questions: What are the climate change effects on the architectural heritage of Maya housing, and what are the adaptation and resilience practices of Maya housing and its environment?

Maya houses have major climate variability adaptation potential. The building of a Maya home is conducted without architects, but with the intensive labor required for the planning, organization, technology and systematic knowledge of the climate on the part of the various artisans involved. These efforts, which we can observe to this day, implied invention, innovation and adaptation, as well as the oral transmission of knowledge for locating and orienting the home, preparing the terrain, seeking out and preparing construction materials, the actual work of building the house and conducting the related construction rituals. There exist various forms of adaptation, among them the form, design, materials and technology used. Here we review the housing's adaptation and resilience to floods, and both water management and control.

The principal objective of this text is to evaluate the adaptative and resilient processes of Maya housing to the effects of climate change, considering the principal criteria / indicators that might affect the habitat's internal environment, its constructive structure, the materials and the inhabitant's comfort, but without changing the Maya house's basic design patterns.

KEY WORDS: Traditional habitat, heritage, Maya house, adaptation, resilience, Mexico 


\section{Introduction}

Hurricanes have been recurrent in the Yucatan Peninsula since pre-Colombian times and especially since the 1980s. Between 1980 and 2005, 9 cyclones were considered disasters in the Gulf of Mexico and the Caribbean. Two of them, hurricanes Gilbert (1988) and Isidore (2002), were particularly destructive.

Over time, the traditional Maya house has deteriorated in some respects, but has yet to disappear. Its flexible structure and renewable materials (the guano palm for the roof, for instance) make for the Maya house's vulnerability to the effects of hurricanes, but it also has especially high adaptation potential. Rather, the traditional Maya house is being threatened by post-disaster reconstruction programs under which governmental authorities draw on a disaster fund (FONDEN) to rebuild such houses with cinder blocks, completely ignoring the patterns and traditional conception of the Maya house. Although the new $24 \mathrm{~m} 2$ house is more resistant to cyclones given its concrete slab roof, in the process traditional and local knowledge is lost along with the cultural elements of the dwelling and its adaptability to hydrometeorological hazards. The heritage of the Maya vernacular house is therefore in danger of disappearing because public reconstruction programs have failed to integrate the traditional elements of the Maya house into the new one. Thus, we are led to demonstrate the following hypothesis: The Maya houses that were destroyed by hurricanes were poorly maintained and poorly built; their replacements were able to withstand cyclones with limited damage.

The current problem is related to Maya housing's adaptation to climate change effects. In order to conduct this study various indicators were considered in relation to the dwelling and its relationship with the environment, geographic location, temperature, illumination, ventilation, orientation, construction systems and materials, sanitation, as well as the other social and economic conditions prevailing in the region, which would provide an approximation of the transformation and climate adaptation the house has experienced.

There exists no "theory" of climate change adaptation, however the fields of anthropology and history have produced various theoretical postures on the subject such as that of Virginia García Acosta ${ }^{1}$, who proposes that "societies around the world and throughout history have formulated social and cultural paths for managing risk and confronting real and potential disasters." Some groups have developed strategies for adapting to environmental, social, technical and cultural change. In this manner the dwelling has adapted to different contents. For that reason, disasters are non-linear, complex, multi-cause and multifactorial processes.

${ }^{1}$ García Acosta V., Estrategias adaptativas y amenazas climáticas, [in:] Más allá del cambio climático, Javier Urbina Soria y Julia Martínez Fernández, compiladores, INE, UNAM, México, 2006, pp. 29-24. 


\section{Theoretical framework: adaptation and resilience to climate change}

We need to reflect on the dialogue between "to inhabit" and climate change effects. Since time immemorial there was awareness of the environment as a determining factor in the culture and development of peoples and that the dwelling formed part not only of the material culture of peoples but also served as an intrinsic element in their development. It is very difficult to deal with this issue without taking into account the various disciplines that have made major contributions to the science of architecture and urbanism.

We have learned from the field of architecture to dialogue with history and the environment. The dwelling, in particular, has to be located in space and time. The anthropologist of Polish origin Amos Rapoport ${ }^{3}$ had posited that climate does not determine the dwelling, but rather represents an important component. In the field of sociology, we are indebted to P. Blaikie, F. Cannon, I. Davis and B. Wisner ${ }^{4}$, as well as Alan Lavell ${ }^{5}$ and Omar Cardona ${ }^{6}$, who have considered both at-risk and vulnerable societies. In the field of disaster history studies, Virginia García Acosta ${ }^{7}$ and her colleagues have argued for the importance of historical perspective in analyzing climate events.

Patrick Pigeon ${ }^{8}$, Jesús Manuel Macías and researchers from the del Instituto Mexicano de Technología del Agua (IMTA), such as Denise Soares ${ }^{9}$, have contributed methods and reflections regarding climate and hydrometeorological events. The work of these researchers demonstrates just how permeable are the transdisciplinary borders in relation to the dwelling and its

1 The verb to dwell, as opposed the noun dwelling. Here we do not regard human settlements as subject, but rather the action of inhabiting.

${ }^{3}$ Rapoport A., House, form and culture, Prentice Hall, NJ, 1969, p. 207.

${ }^{4}$ Blaikie P., Cannon T., Davis I., Wisner B., At Risk, Natural hazards, people's vulnerability and disasters, Routledge, Londres, 1994, p. 284.

${ }^{5}$ Lavell A., Ciencias sociales y desastres naturales en América Latina: un encuentro inconcluso, [in:] Los desastres no son naturales, Andrew Maskrey, compilador, La Red, Bogota, Colombia, 1993.

${ }^{6}$ Cardona O., et al., Entendimiento y gestión de riesgo asociado a las amenazas naturales: un enfoque científico integral para América Latina y el Caribe, Volumen 2, ICSU-LAC-CONACYT, México, 2010, p. 87. ${ }^{7}$ García Acosta V., Las sequías históricas de México, [in:] Desastres \& Sociedad, Revista semestral de la Red de estudios sociales en prevención de desastres en América Latina, Julio-diciembre 1993, №1, Año 1, Bogotá, 1993; García Acosta V., Escobar Ohmstede A., Desastres Agrícolas en México, Catalogo Histórico, Tomo I y II, Fondo de Cultura Económica, Centro de Investigaciones y Estudios Superiores de Antropología Social, CIESAS, México, 2003, p. 280.

${ }^{8}$ Pigeon P., Enjeux et vulnérabilités cachées : évolutions récentes en géographie des risques, [in:] Risques et environnement: recherches interdisciplinaires sur la vulnérabilité des sociétés, Sylvia Becerra, Anne Peltier, (Eds.), Paris, L'Harmattan, 2009, pp. 53-64.

9 Soares D. et al., Capitales de la comunidad, medios de vida y vulnerabilidad social ante huracanes en la costa yucateca. Un acercamiento a través de la experiencia de San Felipe, Yucatán, Centro Agronómico Tropical de Investigación y Enseñanza (CATIE), Turrialba, Costa Rica, 2011, p. 74. 
relationship to the climate and "extreme" climate events. Nevertheless, from a theoretical point of view there exists a contradiction: the dwelling is a process whereas climate is a phenomenon. This is a methodological distinction; the dwelling is studied as a social and technical process, while climate variability is approached as a natural phenomenon in which anthropic actions have altered its development.

We can find the theoretical foundations relative to climate and the adaptation processes of vernacular housing, primarily in the writings of three authors: Amos Rapoport ${ }^{10}$, who regarded climate as a modifying factor of vernacular housing; Paul Oliver ${ }^{11}$, who revealed the need for a new focus on vernacular housing and climate change adaptation; and Valeria Prieto ${ }^{12}$, who conducted the first study on the importance of vernacular housing in Mexico.

Rapoport is constantly amazed by the knowledge and abilities displayed by builders in their choice of sites and climate-adapted materials, and in their adaptations of the traditional model to micro-local climate conditions. In the field of architecture there is a sustained theory of climate causality and of climate requirements determining the form. Rapoport questions this opinion, mentioning the determining role of climate in the creation of the built form while also recognizing that the role of culture is, on numerous occasions, more important than that of climate and, as a result, he questions in this way all extremely determinist opinions. However, the existence of adaptive climate solutions in traditional societies confirms that while climate might not be determinant, it serves as a modifying factor.

Paul Oliver ${ }^{13}$ emphasizes that "primitive construction" remains the absolute archetype and its forms are interpreted as precursors of the architecture of the great, so-called "civilized" societies, when they are product of a culture and of climate change adaptation. This archetype is linked to the concept of "primitive man," hence their constructions are deemed "primitive." The road to recognition of the mere existence of construction forms destined for domestic uses -now referred to as "vernacular architecture"- susceptible to being differentiated according to the location's cultures, environment and climate is one that we can more or less date back to the second half of the Twentieth Century.

P. Oliver ${ }^{14}$ recognizes that climate modifies the concept of some buildings with the problem being the extent to which it is possible to determine whether the response has been a success or failure as very few traditional constructions have been the subject of scientific studies for determining such results.

\footnotetext{
${ }^{10}$ Rapoport A., House, form and culture, Prentice Hall, NJ, 1969.

${ }^{11}$ Oliver P., Cobijo y sociedad, Blume, Madrid, 1978.

${ }^{12}$ Prieto V., Vivienda campesina en México, SAHOP, México, 1978.

${ }^{13}$ Oliver P., Cobijo y sociedad, Blume, Madrid, 1978.

${ }^{14}$ Oliver P., Dwellings, Phaidon, Londres, 2003.
} 
Valeria Prieto ${ }^{15}$ believes that climate conditions constitute one of the main reasons for housing. She states that popular knowledge has been improving on housing designs for adapting them to each climate, and that the process of climate change adaptation is not the result of a sudden decision, but rather of a long process of trial and error.

\section{The local context: climate and hazards}

The Yucatan Peninsula has a 1,941 km coastline with $425 \mathrm{~km}$ corresponding to the state of Campeche, $340 \mathrm{~km}$ to Yucatan con and 1,176 km to Quintana Roo. (Fig. 1)

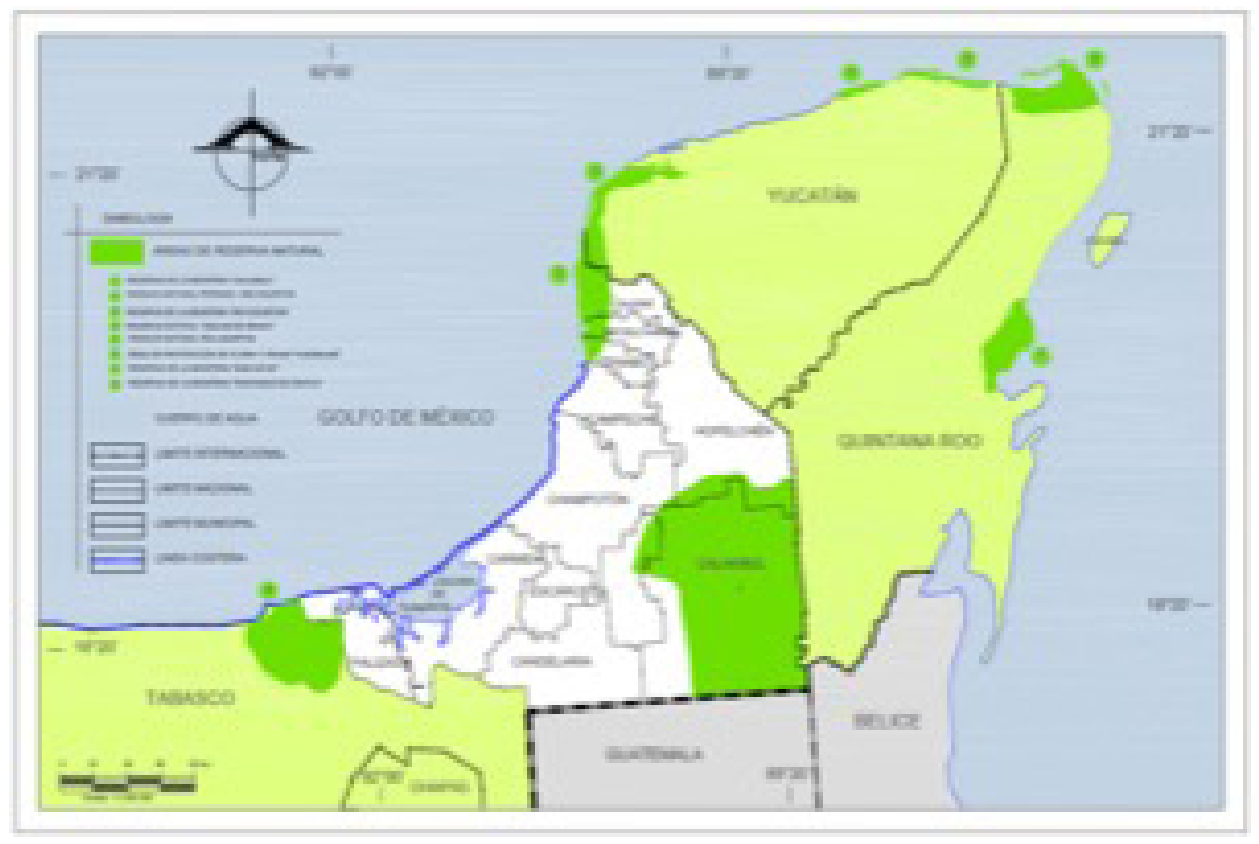

Fig.1 Location of the Yucatan Peninsula. Mexico

In the case of the Yucatan Peninsula, Gilberto proved to be one of the most devastating hurricanes ever to affect the Yucatan given its intensity (category V), producing winds of over $225 \mathrm{Km} / \mathrm{h}$.

A compilation of climate events related to hydrometeorological phenomena on the Yucatan Peninsula between 1464 and 1900 identified a total of 19 extreme events were identified over that 436 year period including hurricanes, excessive rains, epidemics, hurricanes and hail storms; that is a relatively low number of such events excluding the damage inflicted during historical processes manifest over time. Between 1955 and 2016, 39 events consisting of hurricanes, and both tropical depressions and storms were registered in that 61 year period, which is a relatively minor count compared to the mere 19 such events that occurred over a period of 436 years.

${ }^{15}$ Prieto V., Vivienda campesina en México, SAHOP, México, 1978. 


\section{The Maya house and its setting}

According to archeological sources, the Maya house has been in existence for 3,000 years. The choice of materials and the typology were the result of an extended evolutionary process. Despite the urban changes introduced since the Spanish Conquest, the Maya family unit and the solar have persisted throughout history, right up to the present. The solar encompasses the actual house, the kitchen, milpa plot, orchard, vegetable garden, and the corral for the livestock.

The Maya house can be defined by its architectural design and the materials employed in its construction. The following forms have been identified: Apsidal floors with waddle and daub (bajareque) walls, apsidal with stone-work masonry walls, apsidal with walls made of colox-che ${ }^{16}$ unfinished, a rectangular base and waddle and daub walls, a rectangular floor with masonry walls, and a rectangular floor with colox-che' walls unfinished.

The types of houses on the coastal zones include a rectangular floor with walls made of wood and guano palm, a rectangular floor with masonry walls and a guano roof, and a rectangular floor with masonry walls and Marseille style clay tile roof.

The traditional Maya house is closely linked to the local ecosystem. The traditional architecture not only responds to climate conditions, but also to various factors related to the socioeconomic and cultural environments. Studies have shown the persistence of a single model of construction from the pre-Colombian period to the present day. These include Shattuck (1933); Redfield and Villa Rojas (1934) and Wauchope (1938); and Dapuez and Baños (2004). The traditional type of construction can be found throughout the Yucatan Peninsula.

Diego de Landa did not leave us any description regarding the shape of the houses he encountered so we do not know whether just prior to the Conquest they were oblong or rectangular. However, he does mention in his Relaciones de las cosas de Yucatan (Yucatan Before and After the Conquest), the way they were built with the roofs made with abundant palm fronds to keep rainwater from seeping in, and affirms that they were resistant.

Her also mentions hurricanes that flattened high and low-lying houses alike ${ }^{17}$. However, some houses were consumed by fire as their inhabitants had built fires inside the houses as the hurricane hit in order to shield themselves from the cold, but under the impact of the intense winds the waddle of the walls caught fire. Nowadays, the threshold of traditional homes is not very high as a person must bend to enter, but the guano palm roof is well elevated (though they may still catch fire in the event of pyrotechnic displays) and it retains a level of thermal comfort within. There is a possibility the Maya house can be adapted for powerful winds.

${ }^{16}$ When he writes of colox-che' walls, Sánchez Aurelio is referring to the bajareque or waddle and daub system but without the daub in a move designed to allow more light and air to filter in.

${ }^{17}$ de Landa F. D., Relaciones de las cosas de Yucatán, Ed. Porrúa, Historia № 13, México, 1986, chapters $\mathrm{X}, \mathrm{XIV}, \mathrm{XX}$. 
While the walls of the Maya house may be built from trunks, stones or waddle and daub, both the guano palm roofs (Sabal mexicana, Sabal yapa and Sabal mauritiiformis) and the basic structure are comprised of diverse types of wood. The house is approximately $4.5 \mathrm{~m}$ wide, $8.0 \mathrm{~m}$ long and $4.5 \mathrm{~m}$ tall. The roof contains structural elements that allow it to resist hurricanes consisting of two pairs of thin crossbars that serve as roof bracings (called Alkach'o (belcho'). It is possible to use 45 different species of wood for the 22 structural parts (walls and roofs). These are divided into two groups: structural timber and the more flexible ones that are given non structural applications. In the coastal region of San Felipe, Río Lagartos and Las Coloradas, the wooden houses are made from pich (fam. Fabaceae, Enterolobium cyclocarpum) or black zapote wood (fam. Ebenaceae, Diospyros digyna).

The Maya house is adapted to the environment and to hurricanes. This adaptation is due to the:

- Accessibility of local construction materials.

- The wood and guano palm fronds are appropriate for changing temperatures and humidity levels and they provide barrier against infrared and ultraviolet rays and radiation.

- The materials used in the walls maintain a comfortable temperature within.

- The roof's $40^{\circ}$ to $45^{\circ}$ incline helps to repel rainwater.

- The houses can be dismantled and moved to a different location.

- It requires a collective effort.

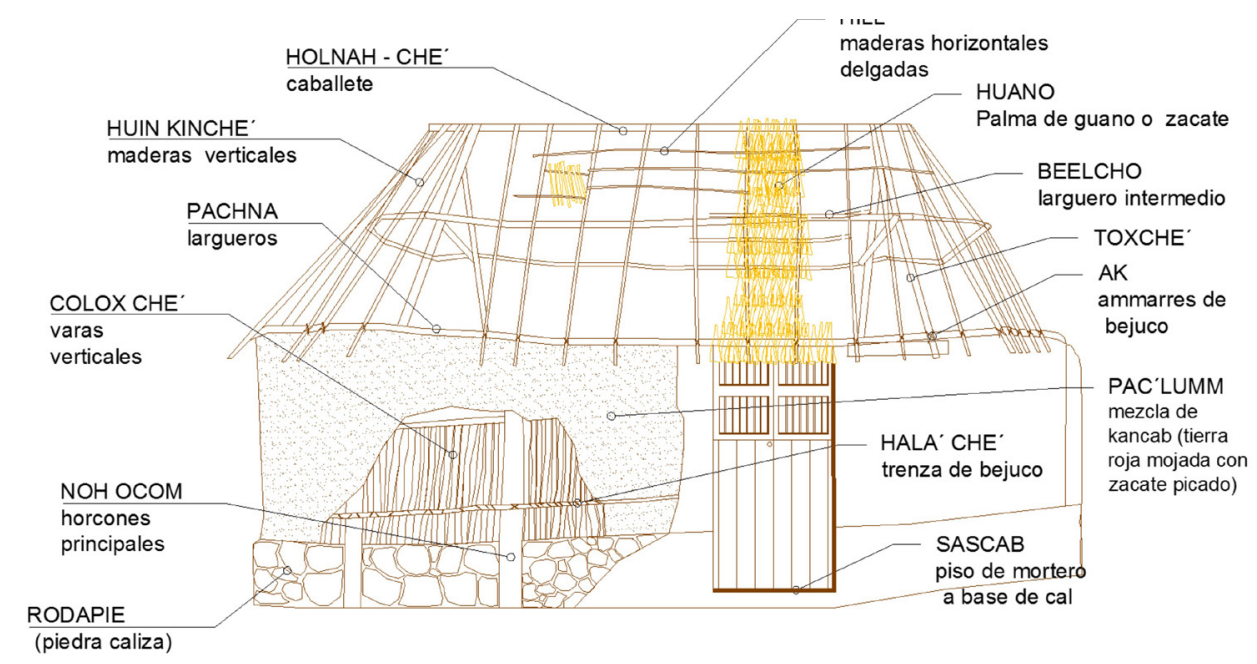

Fig. 2 Maya house with masonry and waddle-and-daub walls 
Traditional houses are resistant to the strong winds of hurricanes. Their structures afford the structural flexibility that allow them to resist intense winds, with the main probable damage consisting of the roof structure possibly leaning away from the wind gusts or the light guano palm fronds being stripped off. The apsidal base and the steeply pitched roof provide wind resistance, helping to easily deflect and divert the wind.

\section{Maya housing's adaptation and resilience potential in relation to the climate and climate change effects}

The two main consequences of climate change that impact the coastal areas of the Yucatan Peninsula are rising sea levels and changes to maritime climate (increasing frequency and intensity of storms and hurricanes).

The Fourth Assessment Report of the United Nations Intergovernmental Panel on Climate Change estimated that sea level rise for 2010 will range between $18-38 \mathrm{~cm}$ (in a low scenario) and $26-59 \mathrm{~cm}$ (in a high scenario), based on multiple emissions scenario models. Climate change will increase flooding and costal erosion going forward. Moreover, more frequent and intense tropical storms and hurricanes are expected, including major storm surges that could also contribute to sea-level rise of 4-6 m or more, which would have a major effect on the coastal states of the Yucatan Peninsula. Such tides could expand the extent of impacted areas by $11 \mathrm{~km}$ to $16 \mathrm{~km}$ inland in the case of low lying areas ( $1-2 \mathrm{~m}$ above sea level).

\section{a) Resistance to hurricanes and precipitation}

Since the pre-Colombian era the inhabitants of Mesoamerica suffered the adverse effects of tropical storms or hurricanes. The god of rain, Tlaloc, appears in one form or another in all Mesoamerican cultures, from the Olmecs at the dawn of the Preclassic period through to Classic Maya culture. In the state of Yucatan and the larger Maya region, hurricanes were the protagonists of cosmogonic myths, as well as in their religions and calendar rituals. From there these myths extended north and south, to wherever there were tornados, dust storms, whirlwinds and waterspouts.

Bartolomé de las Casas interestingly observes in his Apologética historia sumaria that "the Indian's houses with woven vines, which is to say their huts, proved more resistant to hurricanes than those built by Spaniards with boards, heavily festooned with nails". This suggests an early technological adaptation strategy by the indigenous Caribbean peoples against hurricanes.

In this rainy tropical climate, a roof that quickly sheds water is essential for Maya homes: there are two to four sides to the steep pitched roofs to allow water to be quickly repelled from the house. In some cases, builders leave openings along the ridge beam to allow hot air within the house to escap $\mathrm{e}^{18}$. Surrounding plantations, including palm and banana trees and bamboo, also provide protection from hurricanes. The guano palm has a degree of wind resistance. The Maya house is generally located in the lower part of a relief to limit the potential impact of a hurricane.

${ }^{18}$ Prieto V., Vivienda campesina en México, SAHOP, México, 1978. 
On most of the peninsula you see four sided roofs that are rounded in an apsidal pattern to provide the greatest possible wind resistance. The roof's height allows it to trap heat while affording cooler temperatures below. (Fig. 3)

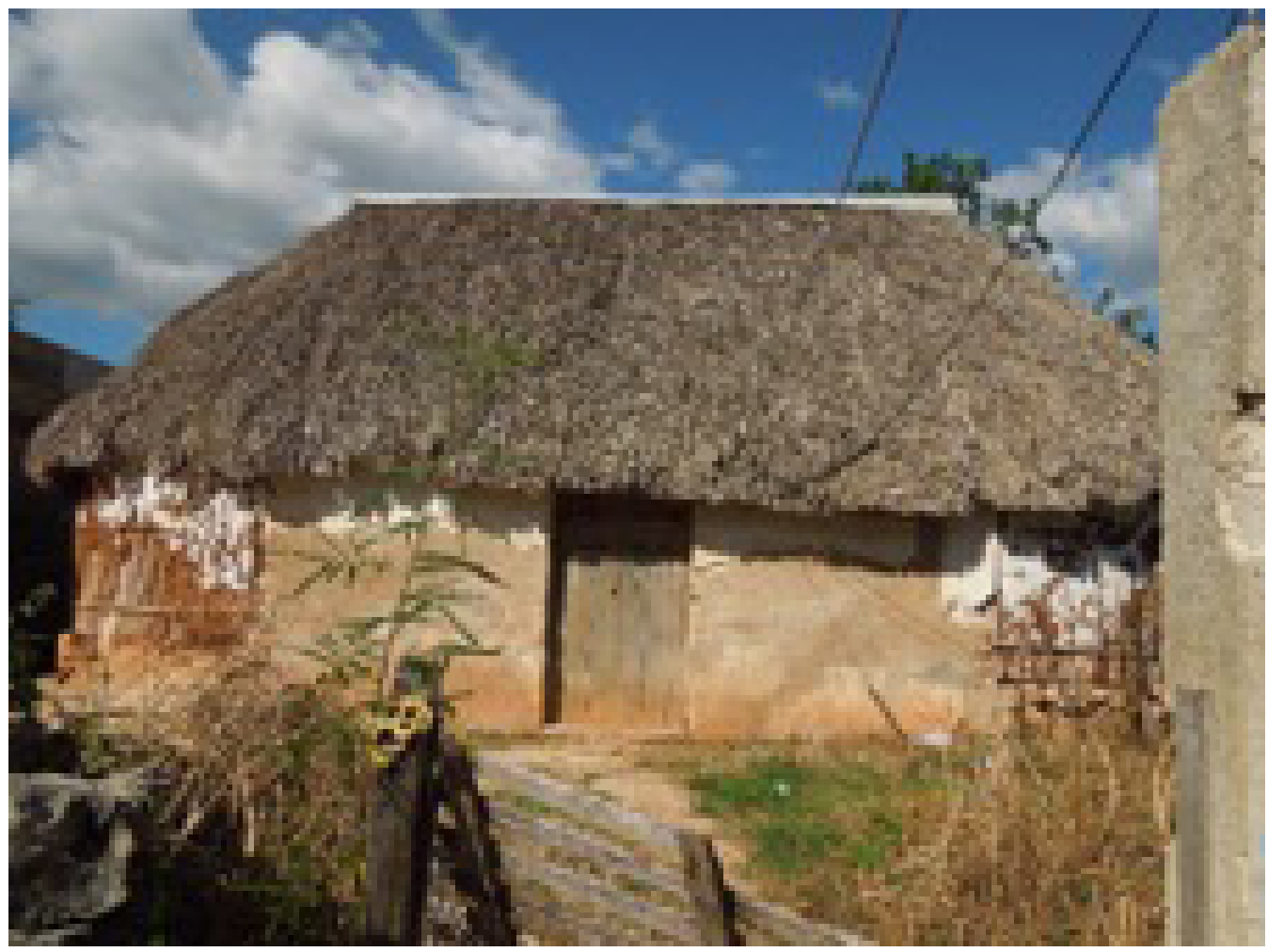

Fig. 3 A Maya dwelling in the Yucatan (Photo B.N. Cabrera)

Dr. Damaso Rivas, a researcher who was born on the Yucatan Peninsula, has recognized the importance of the relationship between the climate within Maya housing, stating that the structure of the ancient Mayas houses includes articulated and flexible characteristics that make them resistant to natural phenomena such as hurricanes ${ }^{19}$. He has worked to revive and develop a new appreciation for Maya housing, citing characteristic elements such as the use of wood and guano that are regarded as sustainable.

${ }^{19}$ Rivas Gutiérrez D., Dámaso Rivas resalta la conveniencia de construir casas mayas. Libertad de expresión Yucatán, Recuperado, 2013, http://www.informaciondelonuevo.com/2013/10/damasorivas-resalta-la-conveniencia-de.html 


\section{b) Adaptability to drought. Ancient and current rain ceremonies}

Ceremonies in the Yucatan for attracting rain have been mentioned by various author ${ }^{20}$. In this context it is understood that there were ceremonies for conjuring the rain. When periods of drought proved to be prolonged it was necessary to conduct rituals for the god of rain Chac. The Maya turned to their priests.

In contemporary Yucatan some rain ceremonies persist (Chak-Chak) such as the one described by Mario Humberto Ruz ${ }^{21}$ in the village of Tixhualahtún in eastern Yucatan:

The h-men prepare the scenario: an altar-table that represents the communal space (Fig. 4), covered with jabín leaves and with the feet of the altar-table firmly rooted in the ground, thereby affording communication with the underworld. Vine arches are erected at each corner. The arches are erected at each of the cardinal points to represent the abodes of the chaakoob, the rain lords. A cross is placed in the center of each arch from which to hang the gourds that will hold the offerings. The gourds are symbolically linked to the celestial sphere that is symbolically extended on the altar. Once the scene has been arranged, the ceremony is held primarily to assure enough rainfall for the crops and the milpa.

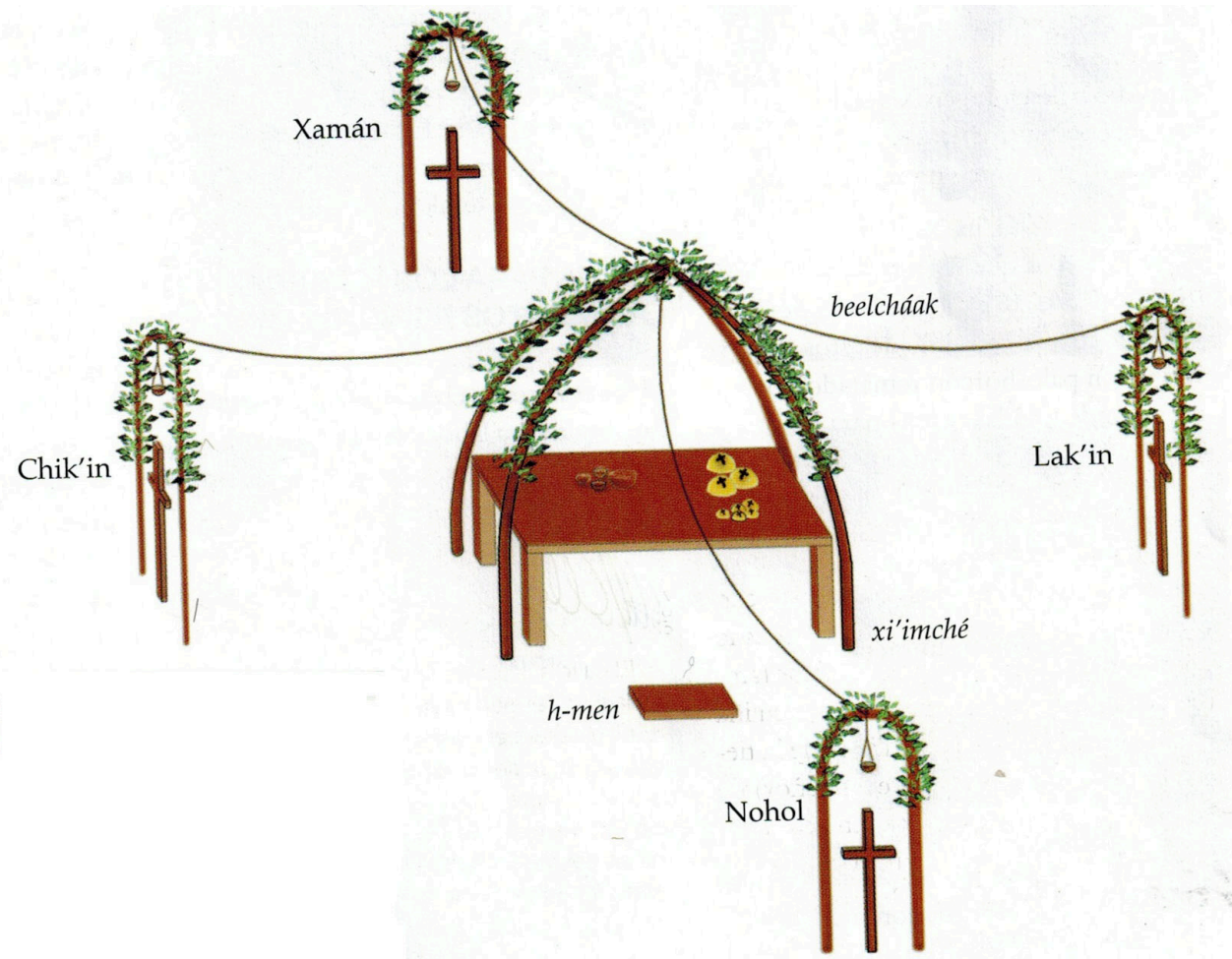

Fig.4 Altar table for summoning the rain lords (Source: Mario Humberto Ruz)

${ }^{20}$ Redfield R., Yucatán, una cultura de transición, FCE, México, 1994; Quezada, S., Los pies de la República, Los mayas peninsulares, 1550-1750, Historia de los pueblos indígenas, INI-CIESAS, 1997, p. 263.

${ }^{21}$ Ruz M. H., Chia Cháak. Plegaria por la lluvia en el Mayab contemporáneo, [in:] Arqueología Mexicana, Dioses de la Lluvia. Nº6, Vol. XVI. marzo-abril, México, 2009, pp. 73-76. 
The work of looking for the timber, vines, and water from wells is a community effort reserved for the men. The ritual liquor and the bread made of think layers of maize and ground pumpkin seeds are prepared. The second day the h-men pinch the maize dough brought by each of the participants, and place a bit from each. In each of the arches are placed offerings of vegetables, maize, cacao, balchée ${ }^{22}$, tabaco, squashes and leaves. Later, the h-men begin their incantations to the rain god. At the conclusion of the ceremony, the altar is dismantled. No one doubts that the rains needed to nurture the milpas are far off.

\section{The Ka'anche'}

Is a $3 \mathrm{~m} 2$ bed made using trunks from the region as well as vines, agaves and grasses to an elevation of $1.50 \mathrm{~m}$. The construction techniques are based on traditional knowledge transmitted from generation to generation. It is generally built as a rectangle ranging from $1.50 \mathrm{~m}$ to 2.00 $\mathrm{m}$ in length, $1.00 \mathrm{~m}$ to $1.50 \mathrm{~m}$ in width, and $1.50 \mathrm{~m}$ to $2.0 \mathrm{~m}$ in height. It is a form of drought adaptation, allowing for cultivation of fruit and vegetable species in a confined and controlled space protected from insects and animals as well as drought. It is one component of the traditional Maya dwelling, integrated as it is into the family compound and is generally located near the family well to facilitate irrigation.

Several authors ${ }^{23}$ mention the Ka'anche', which is used as a ritual table used in the Chak-chak ceremony conducted each August to beseech the rain gods to deliver rainwater to the milpa. The existence of this ceremony is testimony to a history of extended drought in Yucatan. Herman W. Konrad argues that the destruction of the Yucatan Peninsula forests was caused not only by tropical storms and hurricanes, but also by slash and burn agriculture. He also suggests that the success or failure of subsistence strategies in this region depended on the Maya's effective adaptation to the ecological effects of drought and both tropical storms and hurricanes, as suggested by the Ka'anche' technology.

We should also take into account that in pre-Colombian times the Yucatan Peninsula experienced extended droughts. For example, Gill's hypothesis ${ }^{24}$ is based on an explanation for the disappearance of Maya culture resulting from drought in the lowlands between 800 and 1000 $\mathrm{CE}$, and is supported by data and confirming evidence from various disciplines: meteorology, volcanology, paleoclimatology, geology and hydrology. More recently, and possibly in response to climate change effects, there were prolonged droughts during 2008-2011.

\footnotetext{
${ }^{22}$ Balché is an alcoholic beverage made using fermented balaché bark and wheat.

${ }^{23}$ Stephens J. L., Incidentes de viaje en Yucatán, Mérida, 1843; Wauchope R., Modern Maya houses, A study of their archeological significance, Carnegie Inst. of Washington, № 502, Washington D.C., 1938, p. 177; Redfield R., Yucatán, una cultura de transición, FCE, México, 1944.

${ }^{24}$ Gill Richardson B., Las grandes sequías mayas, FCE, México, 2008, pp. 461-465.
} 


\section{Chultuns}

One of the Maya's main technological responses to drought were the canals used to drain excess water from flooded land while retaining the soil's humidity, and the harvesting of rainwater. The storing of water in underground chambers called chultuns, and the systems leading to canals depended on permanent drainage and the capture of seasonal runoff. It has been shown that the two main components of water exploitation, canal building, and construction of irrigation ditches and reservoirs predated the rise of monumental architecture.

Brainerd proposed that the chultuns were already functioning by the Early Classic period (250-600 CE) and that at least by the Late Preclassic (300 BCE - CE 250) they were being built, which is to say that the chultuns already existed in the period when the greatest droughts were experienced, 800-CE-1000 CE. The term chultun, which means a cistern carved from rock to retain rainwater, is made by a contraction of the words chulub (rainwater) and tun (carved stone), according to the Maya Cordemex dictionary.

According to Zapata Peraza a chultun is comprised of (a) a catchment area; (b) mouth; (c) neck; and (d) bed. The catchment area consisted of a slightly inclined apron surrounding the mouth and extending five meters in diameter, thereby guiding the rainwater inward. The mouth generally consists of a monolithic circular ring through which the water enters.

It has a lid made of rock or wood. The neck is divided into two parts: the upper level consists of a ring of stucco-bound stones, and the lower level of bedrock. The neck's entire surface is encased in stucco. The bed comprises the deposit and its walls are always covered with stucco. Maya builders observed that sandy limestone rock was to be found below the superficial layer, and therefore most chultun cavities were formed out of this easily managed material. (Fig. 5) 


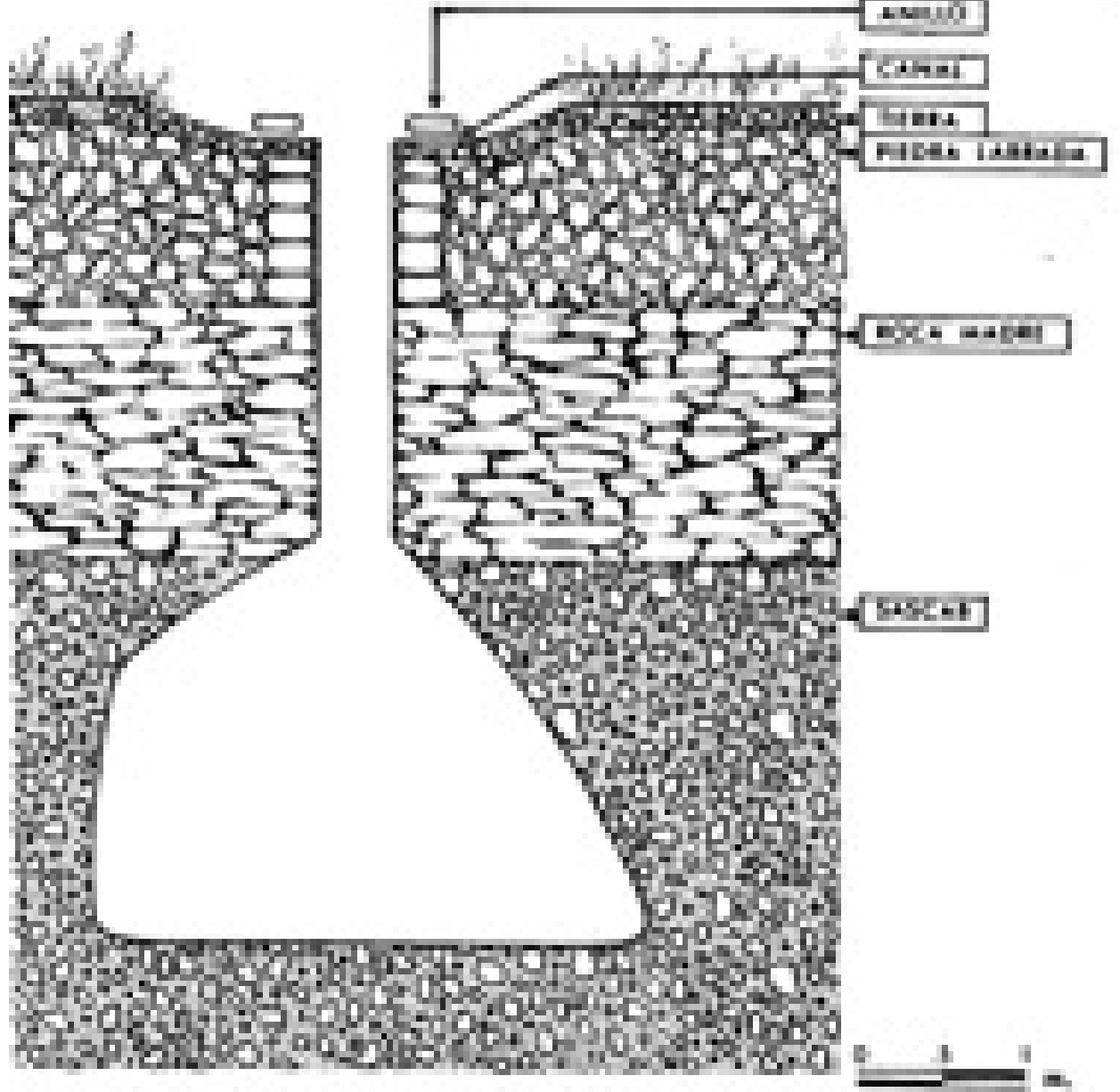

Fig.5 Descriptive image of a chultun (according to Zapata Peraza)

\section{c) Flood adaptation}

Like other countries, Mexico experienced in 1998 and 1999 the warm phase of the El NiñoSouthern Oscillation in the form of torrential rains that led to flooding. A study conducted by the Centro de Investigaciones and Estudios Superiores en Antropología Social (CIESAS) has recorded drought and flooding phenomena from the Pre-Colombian period up to the late Nineteenth Century. In that context, the inhabitants of Mesoamerica have had to adapt their houses to recurring floods, especially those located in humid tropical zones. Rainfall averages $760 \mathrm{~mm}$ per month in Mexico, but $68 \%$ of normal precipitation falls between the months of June and September (CONAGUA). 
Flood adaptation consists of housing placement and site adaptation. Carlos González Lobo ${ }^{25}$ (1999) mentions that "due to its precariousness and necessary insertion in a natural setting, rural housing is, and must be adapted to the site and notable climate has and demands a notable adaptation to the site and the climate. Until now, this has been achieved through observation and the reproduction of socially satisfying means and typologies, and hence the vernacular heritage of the community and users alike. The relationship with the terrain, the direction of rainfall runoff and flash floods, prevailing winds and breezes, sunlight, the slopes corresponding to historical precipitation."

In the Maya zone, for example, some houses are built on a platform, like those built in ceremonial centers. (Fig. 6)

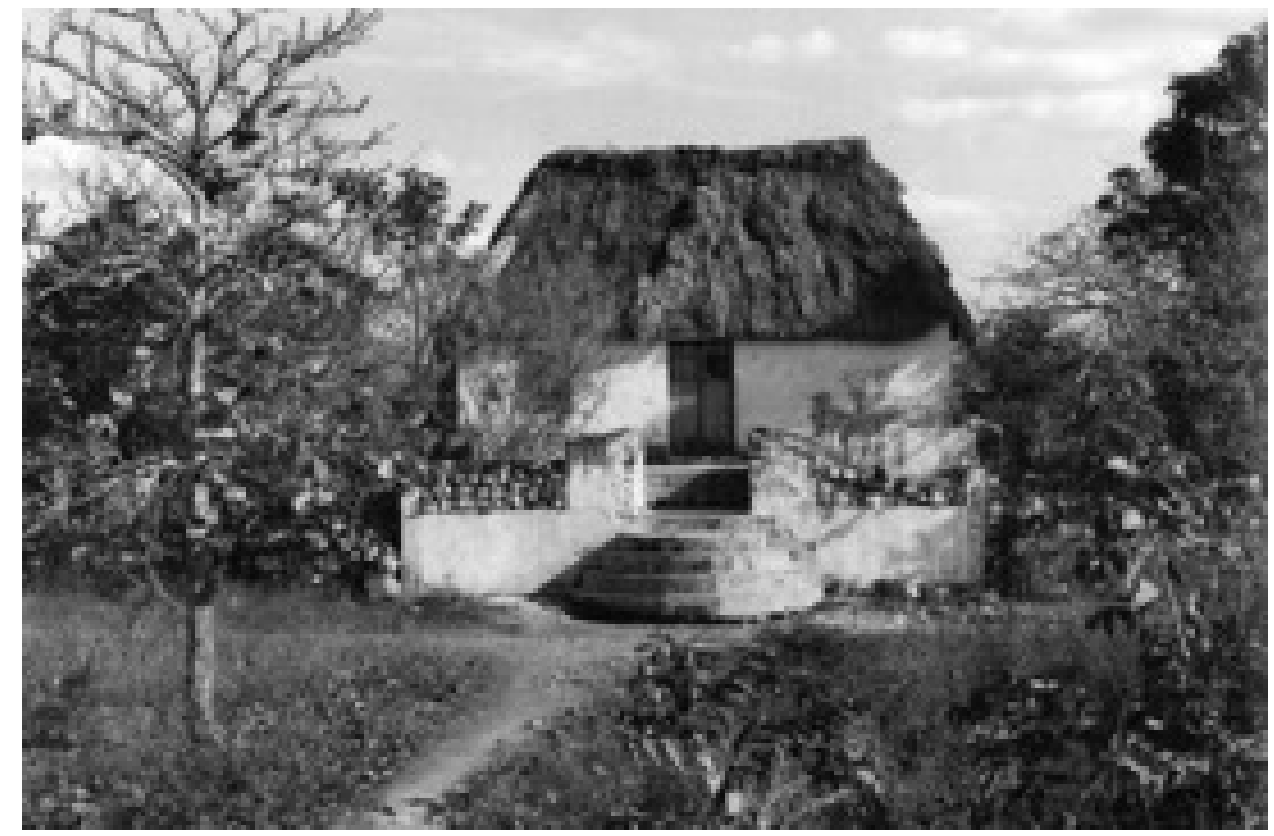

Fig.6 Maya apsidal housing built on a platform in Pomuch, Campeche, (Photo: Mariana Yampolsky, 1993)

There exist various flood adaptation techniques for vernacular housing. These techniques are disappearing along with the houses built using traditional materials. Flood prevention is a modern concept, however, registered traditional houses display a certain prevention process that allow them to avoid the filtration of moisture from the soil using stone foundations and a platform to separate the house from the soil.

\footnotetext{
${ }^{25}$ González Lobo C., La vivienda rural en México, una reflexión sobre su arquitectura y posible intervención, [in:] ler Memoria Seminario Iberoamericano de vivienda y calidad de vida en los asentamientos rurales, 27 de septiembre al $1^{\circ}$ de octubre de 1999, Cuernavaca, Morelos, Jorge González Claverán, Coord., CYTED, México, 1999.
} 


\section{Conclusions: the traditional Maya house's adaptability}

The dwelling does not control the climate, however, it is possible to control and modify the climate within the dwelling even when it is being affected by an adverse outside climate. The inhabitant can control the climate inside the house by means of the materials employed in its construction, as well as its form, and adjacent services and systems. When we speak of climate change adaptation, we are refering to an action taken to affect the conditions within the home, thereby drawing a clear distinction between internal and external space.

One indicator that allows us to understand the habitat/climate relationship is directional orientation. Mesoamerican societies position themselves facing west, with north situated to their right and south to their left, in contrast to the European tradition of using North as the key cardinal point (by which convention cartographers draw standard maps with north at the top). In this tropical forest terrain, hunters can get their bearings in relation to rivers. It is a hydrographic means of orientation rather than the cardinal points used by people in deserts and on the plateau or Antiplano.

The house's orientation depends on the same spatial concept ${ }^{26}$. The geomantic site corresponds to the geographic one, as explained by Pézeu-Masabuau ${ }^{27}$ with regards to the Japanese house.

The social adaptation strategies identified within a contemparaneous Maya family from Cobá shows that the technological adaptation processes were linked to social processes: family or community management of chultuns could only be effective in an organized society sharing an autonomous technologial process. Hence, the combination of social and technological drought adaptation strategies would have made it possible for the Maya to subsist up until the time of the Conquest.

The traditional dwelling is under threat of extinction. Maya housing is being replaced, little by little, with homes built of cinder blocks and concrete slab. In fact, everything is converging toward erasing this heritage:

1. The rules governing the Biosphere Reserve ban the cutting of the pich and zapote trees needed to maintain the wooden houses.

2. The negative impact of the reconstruction programs of the FONDEN trust (Natural Disaster Fund) and the state government with the support of the National Housing Commission (Conavi).

3. The lack of insurance with which to protect this traditional housing heriatage against natural phenomena such as hurricanes.

4. The absence of state programs for improving traditional housing.

\footnotetext{
${ }^{26}$ Audefroy J., Le principe d'Ometeotl, PHD thesis, Université Paris VII, Paris, 1983.

${ }^{27}$ Pézeu-Masabuau J., La maison japonaise, PUF, Paris, 1981.
} 
Few strategies exist for the protection of the Maya habitat from hurricanes. In the absence of a specific home improvement program, and despite the inhabitants recognizing that traditional homes are more inhabitable and better adapted to the tropical heat, they plan to rebuild them with walls made of cinder blocks and concrete roofs. As we have been able to show, walls made of such concrete masonry units lack resistance to saltpeter, but the inhabitants do not clearly perceive this phenomenon.

\section{Acknowledgments}

This study was made possible by support from the Secretariat of Postgraduate Research (SIP), of the Instituto Politécnico Nacional (IPN), for projects numbers 20195755 and 20195369. 


\section{Bibliography}

Audefroy J., Le principe d'Ometeotl, PHD thesis, Université Paris VII, Paris, 1983.

Blaikie P., Cannon T., Davis I., Wisner B., At Risk, Natural hazards, people's vulnerability and disasters, Routledge, Londres, 1994

Cannon T., Reducing People's Vulnerability to Natural Hazards, Research paper N²008/34, UNU-WIDER, Londres, 2008.

Cardona O. et al., Entendimiento y gestión de riesgo asociado a las amenazas naturales: un enfoque científico integral para América Latina y el Caribe, Volumen 2, ICSU-LAC-CONACYT, México, 2010.

Dapuez A. Baños O., Transformaciones en el régimen de la casa maya en Xocén, Revista de la Universidad Autónoma de Yucatán, № 229, Mérida, 2004.

de Landa F. D., Relaciones de las cosas de Yucatán, Ed. Porrúa, Historia No 13, México, 1986.

García Acosta V., Las sequías históricas de México, [in:] Desastres é Sociedad, Revista semestral de la Red de estudios sociales en prevención de desastres en América Latina, Julio-diciembre 1993, №1, Año 1, Bogotá, 1993.

García Acosta V., Escobar Ohmstede A., Desastres Agrícolas en México. Catalogo Histórico, Tomo I y II. Fondo de Cultura Económica, Centro de Investigaciones y Estudios Superiores de Antropología Social, CIESAS, México, 2003.

García Acosta V., Estrategias adaptativas y amenazas climáticas, [in:] Más allá del cambio climático, Javier Urbina Soria y Julia Martínez Fernández, compiladores, INE, UNAM, México, 2006.

Gill Richardson B., Las grandes sequías mayas, FCE, México, 2008.

González Lobo C., La vivienda rural en México, una reflexión sobre su arquitectura y posible intervención, [in:] 1er Memoria Seminario Iberoamericano de vivienda y calidad de vida en los asentamientos rurales, 27 de septiembre al $1^{\circ}$ de octubre de 1999, Cuernavaca, Morelos, Jorge González Claverán, Coord., CYTED, México, 1999.

Herman W. K., Ecological Implications for Pre-Hispanic and Contemporary Maya Subsistence on the Yucatan Peninsula, Revista de la Universidad Autónoma de Yucatán, № 224, Mérida, 2003.

Lavell A., Ciencias sociales y desastres naturales en América Latina: un encuentro inconcluso, [in:] Los desastres no son naturales, Andrew Maskrey, compilador, La Red, Bogota, Colombia, 1993.

Oliver P., Cobijo y sociedad, Blume, Madrid, 1978.

Oliver P., Dwellings, Phaidon, Londres, 2003.

Pézeu-Masabuau J., La maison japonaise, PUF, Paris, 1981.

Pigeon P., Enjeux et vulnérabilités cachées: évolutions récentes en géographie des risques, [in:] Risques et environnement: recherches interdisciplinaires sur la vulnérabilité des sociétés, Sylvia Becerra et Anne Peltier, (Dir), Paris, L'Harmattan, 2009. 
Prieto V., Vivienda campesina en México, SAHOP, México, 1978.

Quezada S., Los pies de la República, Los mayas peninsulares, 1550-1750, Historia de los pueblos indígenas, INI-CIESAS, 1977.

Rapoport A., House, form and culture, Prentice Hall, NJ, 1969.

Redfield R., Yucatán, una cultura de transición, FCE, México, 1944.

Redfield R., Villa Rojas A., Cham Kom a Maya Village, The University of Chicago Press, 1934.

Rivas Gutiérrez D., Dámaso Rivas resalta la conveniencia de construir casas mayas, Libertad de expresión Yucatán, 23 de octubre del 2013; http://www.informaciondelonuevo.com/2013/10/ damaso-rivas-resalta-la-conveniencia-de.html

Ruz M. H., Cha Cháak. Plegaria por la lluvia en el Mayab contemporáneo, [in:] Arqueología Mexicana, Dioses de la Lluvia. N96, Vol. XVI. marzo-abril, México, 2009.

Shattuck G. (Ed.), The peninsula of Yucatán, Medical, Biological and Sociological Studies, Carnegie Inst. Washington D.C, 1993.

Soares D. et al., Capitales de la comunidad, medios de vida y vulnerabilidad social ante huracanes en la costa yucateca. Un acercamiento a través de la experiencia de San Felipe, Yucatán, Centro Agronómico Tropical de Investigación y Enseñanza (CATIE), Turrialba, Costa Rica, 2011..

Stephens J. L., Incidentes de viaje en Yucatán, Mérida, 1843.

Villers Ruiz, L. et al., La unidad de habitación tradicional campesina y el manejo de recursos bióticos en el área maya yucatanense, Biótica Vol. 6, № 3, UNAM, México, 1981.

Wauchope R., Modern Maya houses, A study of their archeological significance, Carnegie Inst. of Washington, No 502, Washington D.C., 1938.

Zapata Peraza, R. L., Los chultunes, sistemas de captación y almacenamiento de agua pluvial, INAH, México, 1989. 